\title{
Project manager's competences in financial industry
}

\author{
Maria Alessandra Montenegro \\ Saga New Frontier Group \\ Belgrade, Serbia \\ alessandra.montenegro@saga.rs
}

\author{
Vladimir Obradović \\ University of Belgrade, Faculty of \\ Organizational Sciences, \\ Belgrade, Serbia \\ vladimiri.obradovic@ fon.bg.ac.rs
}

\author{
Nevenka Žarkić-Joksimović \\ The University of Belgrade, Faculty of \\ Organizational Sciences, \\ Belgrade, Serbia \\ nevenka.zarkic.joksimovic@fon.bg.ac.rs
}

\begin{abstract}
In the last few years, organisations in the financial industry are increasingly applying project management and establishing Project Management Offices. Application of project management in organisations improves effectiveness, efficiency, flexibility, quality etc. Central figure of the project is project manager, and his role is significant for project success. Numerous studies are undertaken to find a project manager`s most essential skills. The overall goal of the study was to find what project managers` skills are the most important in the financial industry and to what extent respondents possess specific skills. Respondents were project managers and project team members from the most prominent financial institutions in Serbia. When it comes to the importance of competences, we found that technical competences are the most critical competences project managers should have in financial industry. PM's self-assessment showed that among technical competences, respondents are good at budgeting and risk management, but on the other hand, they need to develop other critical technical skills such as document\&contract management, procurement and quality management.
\end{abstract}

Keywords-project manager, competences, financial industry.

\section{INTRODUCTION}

The financial industry is a section of the economy made up of firms and institutions that provide financial services to commercial and retail customers. This sector consists of banks, investment companies, insurance companies, and real estate firms [1]. In recent years, financial institutions are increasingly applying project management and establishing Project Management Offices (PMOs). Project Management Institute defines a project as a temporary endeavour taken for producing a unique product, services or result [2]. Application of project management in financial organisations improves effectiveness, efficiency, flexibility, quality etc. Because of the project management's immense importance and more challenging contemporary environment conditions, considerable attention is directed to the central figure of the project - Project Manager. Project manager`s duty is to ensure achieving project objectives. The financial environment creates enormous challenges for project managers and organisations are continually looking for individuals who could successfully lead complex projects. Numerous studies are undertaken to find a project manager most desired skill and the overall goal of this study is to find the essential skills of project managers in the financial industry.

\section{LITERATURE REVIEW}

This chapter shows the previous studies based on project managers' competencies. Robert Katz was one of the first researchers in the field of managerial skills. He was exploring which skills executives need to possess in order to do their job effectively.

Katz suggested three crucial skills for executives: (1) technical, (2) human, and (3) conceptual. According to Katz, technical skill involves specialised knowledge, the analytical ability within that speciality, and facility in the use of the tools and techniques of the specific discipline. Further, human skill is the executive's ability to work effectively as a group member. Finally, conceptual skill is executive's ability to see the enterprise as a whole and to recognise how the various functions depend on one another and how changes in one part can affect all the others [3].

Peterson and Fleet confirmed Katz's work in the managerial skills field. They revised 30 books and textbooks, about management principles, published in the 1980s and early 2000. The result shows that almost all of the books referenced Katz's work [4].

Project Management Institute confirmed the importance of technical, interpersonal, and conceptual skills of project managers [2]. According to IPMA, the competences in the project environment are divided into three categories (a) People - Personal and interpersonal qualities required for managing projects, (b) Practice - Competences related to technical aspects of project management and (c) Perspective Competitive Competencies Required within a Specific Environment [5].

Sunindijo and Zou in their paper, CHPT construct: essential skills for construction project manager", acknowledged Katz`s work but also proposed political competences as an additional relevant category [6]. Pinto acknowledged the importance of political skills for project managers. He explained that political processes are very represented in the field of project 
management. Project management is essential in various industries [7]

Project managers often don`t have a stable base of power, so they need to influence others to provide resources to attain project success [8]. Figure 1. presents CHPT construct.

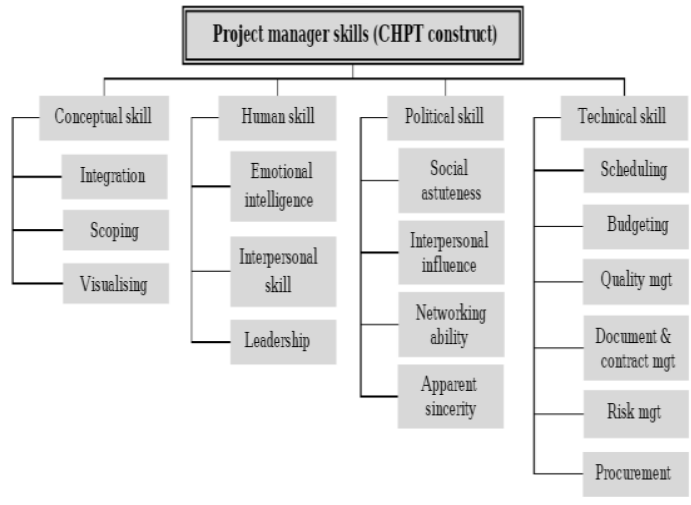

Fig. 1. Project manager skills -CHPT construct

\section{METHODS}

CHPT concept was used as a base for the conducted research. The research aimed to examine the importance of conceptual, human, political and technical competences for project managers in the financial industry. As it is shown in the figure 1., competences are classified into four categories (1) conceptual, (2) human, (3) political and (4) technical and their subcategories (1.1.) project integration, (1.2.) project scoping, (1.3.) visualizing, (2.1.) emotional intelligence, (2.2.) interpersonal skill, (2.3) leadership, (3.1) social astuteness, (3.2) interpersonal influence, (3.3.) networking ability, (3.4.) apparent sincerity, (4.1.) scheduling, (4.2.) budgeting, (4.3.) quality management, (4.4.) document\&contract management, (4.5.) risk management, (4.6.) procurement [6]. The conducted research aimed to find: 1) what previously mentioned project manager's skills are the most important for PMs working in the financial industry and 2) to what extent current PMs possess these skills. Respondents were 30 employees (15 project managers and 15 project team members) from the most eminent banks and insurance companies in Serbia.

The questionnaire had following structure: (1) 8 general questions - gender, age, years of work experience, level of education, type of financial institution respondent works (bank/insurance company), existence of PMO and number of employees in the organization respondent works, respondent's position in the organization (PM or team member) (2) 16 questions that evaluated importance of each project manager's skill (form 1 to 5) and (3) 16 questions that required project manager's selfassessment about each skill. In the second part of the questionnaire, project managers and project team members answered to the questions like "To what extent do you consider that specific skill is significant for project managers?", while the third part was for project managers only, and the questions were like "To what extent do you think you possess a certain skill?". The results of the research are presented in the following section.

\section{RESULTS AND DISCUSSION}

In this section, we present the results of the research. $60 \%$ of the total number of respondents are women, while men are $40 \%$ of respondents. Regarding education, $50 \%$ of the respondents have a bachelor degree, $40 \%$ a master degree and $10 \%$ a high school degree. The largest number of respondents (70\%) work in banks, while a smaller number of respondents $(30 \%)$ are from insurance companies. $30 \%$ of respondents have more than ten years of work experience, $20 \%$ between 5 and 10 years and $50 \%$ of respondents have less than five-year work experience. Interestingly, $100 \%$ of respondents work in organisations where to exist Project Management Office as a separate sector, which is a very positive phenomenon. Also, $70 \%$ of respondents work in organisations with over 1.000 employees, $20 \%$ in organisations with between 250 and 1000 employees and only $10 \%$ of respondents work in organisations with less than 250 employees.

TABLE I. THE PROFILE OF RESPONDENTS

\begin{tabular}{|c|c|c|c|}
\hline \multirow{2}{*}{ No } & \multicolumn{3}{|c|}{ Profile of the respondents } \\
\hline & Variable & Category & Percentage \\
\hline \multirow{2}{*}{1.} & \multirow{2}{*}{ Gender } & Female & $60 \%$ \\
\hline & & Male & $40 \%$ \\
\hline \multirow{3}{*}{2.} & \multirow{3}{*}{ Level of education } & $\begin{array}{l}\text { High school } \\
\text { degree }\end{array}$ & $10 \%$ \\
\hline & & Bachelor degree & $50 \%$ \\
\hline & & Master degree & $40 \%$ \\
\hline \multirow{3}{*}{3.} & \multirow{3}{*}{$\begin{array}{l}\text { Total years of work } \\
\text { experience }\end{array}$} & Less than 5 years & $50 \%$ \\
\hline & & $\begin{array}{c}\text { Between } 5 \text { and } 10 \\
\text { years }\end{array}$ & $20 \%$ \\
\hline & & $\begin{array}{c}\text { More than } 10 \\
\text { years }\end{array}$ & $30 \%$ \\
\hline \multirow[b]{2}{*}{4.} & \multirow{2}{*}{$\begin{array}{l}\text { Type of Financial } \\
\text { Institution } \\
\text { respondent works }\end{array}$} & Bank & $70 \%$ \\
\hline & & $\begin{array}{l}\text { Insurance } \\
\text { Company }\end{array}$ & $30 \%$ \\
\hline \multirow[t]{2}{*}{5.} & \multirow{2}{*}{$\begin{array}{l}\text { Existence of PMO in } \\
\text { respondent`s } \\
\text { organisation }\end{array}$} & Yes & $100 \%$ \\
\hline & & No & $0 \%$ \\
\hline \multirow{3}{*}{6.} & \multirow{3}{*}{$\begin{array}{l}\text { No. of employees in } \\
\text { organisation } \\
\text { respondents works }\end{array}$} & Less then 250 & $10 \%$ \\
\hline & & $\begin{array}{c}\text { Between } 250 \text { and } \\
1000\end{array}$ & $20 \%$ \\
\hline & & More then 1000 & $70 \%$ \\
\hline \multirow{2}{*}{7.} & \multirow{2}{*}{$\begin{array}{l}\text { Respondent`s } \\
\text { position in the } \\
\text { organisation }\end{array}$} & $\mathrm{PM}$ & $50 \%$ \\
\hline & & Team member & $50 \%$ \\
\hline
\end{tabular}


How the respondents were from different positions in the organisations, we were interested in finding the difference in attitudes between project managers and project team members. Project managers consider that the most valuable skills for PMs in the financial industry are: project scoping, risk management, scheduling, project integration, budgeting and interpersonal skills. It can be noted that PMs attach great importance to technical skills. On the other hand, team members, in addition to technical (scheduling and budgeting), attach great importance to project visioning, leadership and interpersonal skills. The results are shown in the table 2.

TABLE II. DifFERENCE Between Project MANAGERS AND TEAM MEMBERS REGARDING COMPETENCE IMPORTANCE

\begin{tabular}{|c|c|c|c|c|}
\hline \multirow[t]{2}{*}{ No. } & \multicolumn{2}{|c|}{$\begin{array}{c}\text { Project Managers' } \\
\text { attitudes }\end{array}$} & \multicolumn{2}{|c|}{$\begin{array}{c}\text { Team members' } \\
\text { attitudes }\end{array}$} \\
\hline & Competency & $\begin{array}{l}\text { Average } \\
\text { value }\end{array}$ & Competency & $\begin{array}{l}\text { Average } \\
\text { value }\end{array}$ \\
\hline 1. & Scoping & 4,87 & Scheduling & 4,67 \\
\hline 2. & $\begin{array}{c}\text { Risk } \\
\text { management }\end{array}$ & 4,80 & Visioning & 4,67 \\
\hline 3. & Scheduling & 4,60 & Budgeting & 4,60 \\
\hline 4. & Integration & 4,60 & Leadership & 4,47 \\
\hline 5. & Budgeting & 4,60 & $\begin{array}{c}\text { Interpersonal } \\
\text { skill }\end{array}$ & 4,47 \\
\hline 6. & $\begin{array}{l}\text { Interpersonal } \\
\text { skill }\end{array}$ & 4,60 & $\begin{array}{l}\text { Apparent } \\
\text { sincerity }\end{array}$ & 4,40 \\
\hline 7. & $\begin{array}{l}\text { Apparent } \\
\text { sincerity }\end{array}$ & 4,53 & Integration & 4,40 \\
\hline 8. & Visioning & 4,33 & $\begin{array}{l}\text { Emotional } \\
\text { intelligence }\end{array}$ & 4,33 \\
\hline 9. & $\begin{array}{c}\text { Quality } \\
\text { management }\end{array}$ & 4,33 & Networking & 4,33 \\
\hline 10. & Leadership & 4,33 & $\begin{array}{c}\text { Risk } \\
\text { management }\end{array}$ & 4,33 \\
\hline 11. & Networking & 4,20 & Scoping & 4,27 \\
\hline 12. & $\begin{array}{c}\text { Document \& } \\
\text { contract } \\
\text { management }\end{array}$ & 4,20 & $\begin{array}{c}\text { Document \& } \\
\text { contract } \\
\text { management }\end{array}$ & 4,13 \\
\hline 13. & $\begin{array}{l}\text { Interpersonal } \\
\text { influence }\end{array}$ & 4,20 & $\begin{array}{c}\text { Interpersonal } \\
\text { influence }\end{array}$ & 4,13 \\
\hline 14. & $\begin{array}{c}\text { Social } \\
\text { astuteness }\end{array}$ & 4,13 & $\begin{array}{c}\text { Social } \\
\text { astuteness }\end{array}$ & 4,13 \\
\hline 15. & $\begin{array}{c}\text { Emotional } \\
\text { intelligence }\end{array}$ & 4,13 & $\begin{array}{c}\text { Quality } \\
\text { management }\end{array}$ & 4,07 \\
\hline 16. & Procurement & 4,06 & Procurement & 3,53 \\
\hline
\end{tabular}

There was a difference in the significance of competences between men and women. Men who work in the financial industry, consider that the five most important competences for project managers are budgeting, scheduling, scoping, risk management and apparent sincerity. It can be noted that there are as many as three technical competences. Unlike men, women consider that the five most important competences are project visioning, interpersonal skill, leadership, risk management and budgeting. Women highly appreciate the importance of human competences. However, they both consider the importance of risk and budget management for PMs. When we compare respondents with different years of experience, we can see that respondents with less than
5 years of experience believe that the PM's most important skills are: budgeting, scoping, scheduling, apparent sincerity, and project visioning. So, in their opinion, technical and conceptual skills prevail. Respondents with experience between 5 and 10 years believe that the most important skills are risk management, scoping, procedures, quality and budgets. Surprisingly, as many as 4 out of the five most important skills are technical competences. Respondents with over 10 years of experience believe that interpersonal skill, scheduling, risk, budgeting and scoping are the most important skills Respondents from different size organizations also have different opinions; respondents working in financial institutions with less than 250 employees emphasize the importance of political competences (apparent sincerity, networking, interpersonal influence, social astuteness and leadership). Respondents working in organisations with more than 250 people nevertheless increasingly respect technical skills (risk, quality, budgeting, scheduling).

The third part of the research was the project manager's self-assessment. Respondents were answering the question, To what extent do you think you possess a specified skill?". Project managers estimate that they are the best in interpersonal skills. Also, respondents consider themselves as individuals of integrity. They can manage the scope of the project. Of the technical capabilities, they stand out in budgeting and managing the project risk. The results are shown in the table 3 .

TABLE III. The Results of Project Managers`SelfASSESSMENT

\begin{tabular}{|l|c|c|}
\hline No. & Competency subcategory & Average value \\
\hline 1. & Interpersonal skill & 4,40 \\
\hline $\mathbf{2 .}$ & Budgeting & 4,27 \\
\hline $\mathbf{3 .}$ & Apparent sincerity & 4,27 \\
\hline $\mathbf{4 .}$ & Integration & 4,27 \\
\hline $\mathbf{5 .}$ & Risk management & 4,20 \\
\hline $\mathbf{6 .}$ & Networking & 4,13 \\
\hline $\mathbf{7 .}$ & Emotional intelligence & 4,13 \\
\hline $\mathbf{8 .}$ & Scoping & 4,13 \\
\hline $\mathbf{9 .}$ & Scheduling & 4,07 \\
\hline $\mathbf{1 0 .}$ & Visioning & 4,07 \\
\hline $\mathbf{1 1}$ & Leadership & 4,00 \\
\hline $\mathbf{1 2 .}$ & Social astuteness & 3,93 \\
\hline $\mathbf{1 3 .}$ & Interpersonal influence & 3,87 \\
\hline $\mathbf{1 4 .}$ & Document \& contract management & 3,87 \\
\hline $\mathbf{1 5 .}$ & Procurement & 3,73 \\
\hline $\mathbf{1 6 .}$ & Quality management & 3,67 \\
\hline & & \\
\hline
\end{tabular}




\section{CONCLUSION}

The results of this study indicate that project managers acknowledge the importance of having technical project management skills for work in the financial industry. It is highly important for PMs to manage project costs and deadlines, and to be sure that everything is in accordance with the contract. On the other hand, project team members, though they do not underestimate the importance of technical skills, emphasise the importance of leadership and interpersonal skills. There was a difference between men and women. Men attach more importance to technical skills than women. Women value more competences like project visioning, interpersonal skill and leadership. Also, there was a difference between different-size organisations. In smaller organisations, political skills are critical (apparent sincerity, networking, interpersonal influence, social astuteness) while in larger organisations, employees attach more importance to technical skills.

Although in recent years, more and more attention has been paid to the social and conceptual skills of PMs, in the financial industry still prevails the importance of technical skills. All categories of respondents highly rank the technical competencies of PMs. Financial institutions are known as a rigid institution, so it is not surprising that project managers in this industry must be in strict compliance with deadlines, budgets, risk management, quality, procedures, etc.

In the end, PM's self-assessment showed that they are good at budgeting, risk management, project integration and interpersonal skill. However, there is a lack of other essential technical skills, such as document \& contract management, procurement and quality management. These skills are crucial for successful project management, and the responsibility of HR managers in the future is to develop these skills with project managers in their organisations.

\section{ACKNOWLEDGEMENT}

This paper is a result of the Project No. 179081 funded by Ministry of Education and Science of the Republic of Serbia: Researching Contemporary Tendencies of Strategic Management Using Specialized Management Disciplines in Function of Competitiveness of Serbian Economy.

\section{REFERENCES}

[1] W. Kenet, "Financial Sector", taken from https://www.investopedia.com/terms/f/financial sector.asp, date accessed 22.04.2019.

[2] Project Management Institute, "A Guide to the Project Management Body of Knowledge: PMBOK Guide", Fourth Edition, Pennsylvania: USA, 2008

[3] R. L. Katz, "Skills of an Effective Administrator", Harvard Business Review Sep-Oct, 1974, pp.91-93

[4] T. O. Peterson, and D. D. V. Fleet, "The ongoing legacy of R.L. Katz: an updated typology of management skills", Management Decision, Vol. 42, No. 10, 2004, pp.1297-1308.

[5] Individual Competence Baseline for Project, Programme and Portfolio Management, International Project Management Association (IPMA), 2015.

[6] R. Y. Sunindijo, and P. X. W. Zou, "CHPT construct: essential skills for construction project managers", International Journal of Project Organisation and Management, 2011, pp.139-163.

[7] V. Obradovic, P. Jovanovic, N. Djordjevic, I. Beric, F. Jovanovic, "Using project management as a way to excellence in healthcare", HealthMED, 2012, pp. 2100-2107.

[8] J. Pinto, "Understanding the Role of Politics in Successful Project Management", International Journal of Project Management, 2000, pp. 85-91. 